\title{
EFFECT OF PRESTRESS AND STRESS ON THE STRENGTH AND OXIDATION RATE OF NUCLEAR GRAPHITE
}

\author{
M. Eto and F.B. Growcock
}

Date Published - September 1981

\section{DO NOT MICROFILM COVER}

\author{
HTGR SAFETY DIVISION \\ DEPARTMENT OF NUCLEAR ENERGY, BROOKHAVEN NATIONAL LABORATORY \\ UPTON, NEW YORK 11973
}

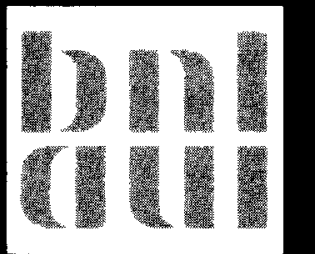




\section{DISCLAIMER}

This report was prepared as an account of work sponsored by an agency of the United States Government. Neither the United States Government nor any agency Thereof, nor any of their employees, makes any warranty, express or implied, or assumes any legal liability or responsibility for the accuracy, completeness, or usefulness of any information, apparatus, product, or process disclosed, or represents that its use would not infringe privately owned rights. Reference herein to any specific commercial product, process, or service by trade name, trademark, manufacturer, or otherwise does not necessarily constitute or imply its endorsement, recommendation, or favoring by the United States Government or any agency thereof. The views and opinions of authors expressed herein do not necessarily state or reflect those of the United States Government or any agency thereof. 


\section{DISCLAIMER}

Portions of this document may be illegible in electronic image products. Images are produced from the best available original document. 


\title{
EFFECT OF PRESTRESS AND STRESS ON THE STRENGTH AND OXIDATION RATE OF NUCLEAR GRAPHITE
}

\author{
M. Eto and F.B. Growcock
}

NUREG/CR--2316

TI86 000181

\section{DISCLAIMER}

This report was prepared as an account of work sponsored by an agency of the United States Government. Neither the United States Government nor any agency thereof, nor any of their employees, makes any warranty, express or implied, or assumes any legal liability or responsibility for the accuracy, completeness, or usefulness of any information, apparatus, product, or process disclosed, or represents that its use would not infringe privately owned rights. Reference herein to any specific commercial product, process, or service by trade name, trademark, manufacturer, or otherwise does not necessarily constitute or imply its endorsement, recommendation, or favoring by the United States Government or any agency thereof. The views and opinions of authors expressed herein do not necessarily state or reflect those of the United States Government or any agency thereof.

\section{HTGR SAFETY DIVISION, DEPARTMENT OF NUCLEAR ENERGY BROOKHAVEN NATIONAL LABORATORY, ASSOCIATED UNIVERSITIES, INC. UPTON, NEW YORK 11973}

\section{PREPARED FOR THE UNITED STATES NUCLEAR REGULATORY COMMISSION DIVISION OF REACTOR SAFETY RESEARCH, OFFICE OF NUCLEAR REGULATORY RESEARCH UNDER CONTRACT NO. DE-ACO2-76CH0O016 NRC FIN A-3016}




\section{DISCLAIMER}

This report was prepared as an account of work sponsored by an agency of the United States Government. Neither the United States Government nor any agency thereof, nor any of their employees, nor any of their contractors, subcontractors, or their employees, makes any warranty, express or implied, or assumes any legal liability or responsibility for the accuracy, completeness, or usefulness of any information, apparatus, product, or process disclosed, or represents that its use would not infringe privately owned rights. Reference herein to any specific commercial product, process, or service by trade name, trademark, manufacturer, or otherwise, does not necessarily constitute or imply its endorsement, recommendation, or favoring by the United States Government or any agency, contractor or subcontractor thereof. The views and opinions of authors expressed herein do not necessarily state or reflect those of the United States Government or any agency, contractor or subcontractor thereof.

Printed in the United States of America Available from

National Technical Information Service

U.S. Department of Commerce

5285 Port Royal Road

Springfield, VA 22161

NTIS price codes:

Printed Copy: A02; Microfiche Copy: A01 


\section{ABSTRACT}

Effects of prestress or stress during oxidation on the reactivities and strengths of $\mathrm{PGX}$ and $\mathrm{H} 451$ graphites were examined at oxidation temperatures of $450-600^{\circ} \mathrm{C}$ in air and $550-750^{\circ} \mathrm{C}$ in $2 \% \mathrm{H}_{2} \mathrm{O} / \mathrm{He}$. Little or no effect of compressive prestress at stress levels of up to $75 \%$ of the mean fracture strengths, was found. A small effect on the reactivity of $H 451$ graphite was observed in the case of $2 \% \mathrm{H}_{2} \mathrm{O} / \mathrm{He}$, i.e. the rate was enhanced by no more than $30 \%$ for compressive prestress levels of up to $90 \%$ of the fracture strength.

Tensile and compressive stresses during oxidation did not affect the reactivities of these graphites at stress levels of up to $28 \%$ of the mean compressive strength and $35 \%$ of the mean tensile srength for $\mathrm{H} 451$ graphite, and $44 \%$ and $56 \%$ for PGX graphite, respectively. 
ABSTRACT ................................

List of figures ..................... v

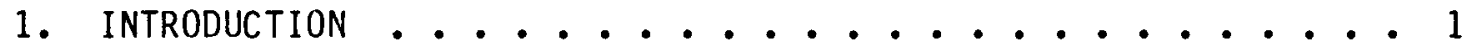

2. EXPERIMENTAL ...................... 1

2.1 Materials ................... 1

2.2 Experiments on Tensile and Compressive Stresses before 0xidation ............. 2

2.3 Experiments on Tensile and Compressive Stresses during 0xidation. ............. 4

2.4 Measurements of Reaction Rate ........... 4

3. RESULTS AND DISCUSSION ............ . . 7

3.1 Effect of Prestress on Strength and Oxidation Rate . . . 7

3.2 Effect of Stress during Oxidation on Reaction Rate . . . 20

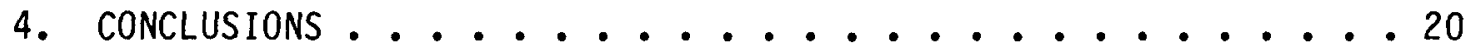

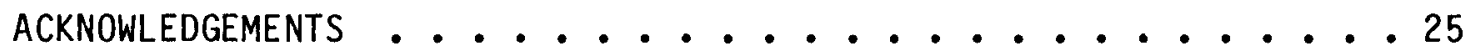

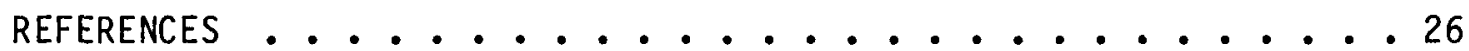




\section{LIST OF FIGURES}

Figure

Title

Page

1

2

3

4

5

6

7

8

9

10

11

12

13

Dimensions of the specimens used in the present experiments: (A) and (B), compressive specimen;

(C) tensile specimen for stress rig......... 3

Schematic of the main part of the stress rig ..... 5

Overview of the stressing experiment . . . . . . 6

Compressive strength of prestressed or non-stressed $P G X$ graphite oxidized in air or in $2 \% \mathrm{H}_{2} \mathrm{O} /\left(20 \% \mathrm{H}_{2}\right) / \mathrm{He}$

at different temperatures ............ 8

Compressive strength of prestressed or non-stressed

$\mathrm{H} 451$ graphite oxidized in air or in $2 \% \mathrm{H}_{2} \mathrm{O} / \mathrm{He}$ at

various temperatures ..............

Reaction rate of $P G X$ graphite specimens prestressed to various levels and oxidized in air at $500^{\circ} \mathrm{C}$ as a function of exposure time ................

Reaction rate of $P G X$ graphite oxidized in $2 \% \mathrm{H}_{2} \mathrm{O} / \mathrm{He}$ at $700^{\circ} \mathrm{C}$ as a function of exposure time ........

Rate of oxidation of $\mathrm{H} 451$ graphite in air at $500^{\circ} \mathrm{C}$ as a function of exposure time.............. 11

Rate of oxidation of $\mathrm{H} 45 \mathrm{l}$ graphite in air at $550^{\circ} \mathrm{C}$ as a function of exposure time .............. 11

Rate of oxidation of $\mathrm{H} 451$ graphite in $2 \% \mathrm{H}_{2} \mathrm{O} / \mathrm{He}$ at $750^{\circ} \mathrm{C}$ as a function of exposure time ............

Reaction rate as a function of exposure time for the $\mathrm{H} 45 \mathrm{l}$ graphite specimen shown in Figure 10 after $40 \mathrm{hr}$ of exposure

Reaction rate of an $\mathrm{H} 451$ control specimen, which was prestressed to $75 \%$ of the mean compressive strength before the first run, as a function of exposure time.....

Reaction rate of an $\mathrm{H} 451$ graphite specimen which was prestressed in stepwise fashion and oxidized in $2 \% \mathrm{H}_{2} \mathrm{O} / \mathrm{He}$ at $750^{\circ} \mathrm{C}$ 


\section{LIST OF FIGURES (Cont'd.)}

Figure

Title

Page

14

Stabilized reaction rate of $\mathrm{H} 451$ graphite specimen

which was prestressed in stepwise fashion as a

function of normalized prestress level . . . . . 12

15

Reaction rate vs. exposure time of $P G X$ graphite subjected to various levels of stress while being oxidized at $440^{\circ} \mathrm{C}$ in $2 \% \mathrm{H}_{2} \mathrm{O} / \mathrm{He}$. . . . . . . . 14

16 Reaction rate vs. exposure time of $P G X$ graphite oxidized under stress at $650^{\circ} \mathrm{C}$ in $2 \% \mathrm{H}_{2} \mathrm{O} / \mathrm{He}$..... 14

17 Reaction rate vs. exposure time of PGX graphite subjected to various stress levels while being oxidized at $650^{\circ} \mathrm{C}$

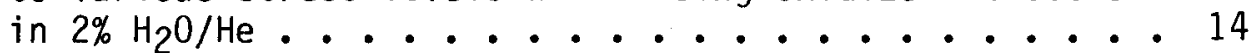

18 Reaction rate vs. exposure time of $\mathrm{H} 451$ graphite subjected to various levels of stress while being oxidized at $700^{\circ} \mathrm{C}$ in $2 \% \mathrm{H}_{2} \mathrm{O} / \mathrm{He}$......... 14 


\section{INTRODUCTION}

In high temperature gas-cooled reactors (HTGRs), nuclear graphite is used as structural material, as well as moderator and reflector. Mechanical strength is one of the most important properties by which structural graphite is judged. During normal reactor operation or following an accident that leads to depressurization, impurity gases in the helium coolant may oxidize the graphite and compromise the integrity of the reactor core and core support regions; in addition, the graphite components are subjected to various types of stresses. Evaluation of the effect of stress on the oxidation behavior and strength of nuclear graphite is believed to be important in terms of the design and safety analysis of the reactors.

It is well known that prestress or stress can cause pronounced changes in some physical and mechanical properties of graphite.2-7 No studies on oxidation of the material have, however, been reported in which both prestress and stress were investigated. Krefeld et al.8 first reported that a tensile stress of $20 \mathrm{~kg} / \mathrm{cm}^{2}$ (ca. $2 \mathrm{MN} / \mathrm{m}^{2}$ ) enhanced the oxidation rates of several graphites by a factor of ca. 3 and decreased their ultimate tensile strengths by $\mathrm{ca}$. $10 \%$ compared with unstressed specimens. Kubaschewski et al.9 obtained no enhancement of the oxidation rates of similar graphites exposed to a wide range of tensile stress, and Growcock and Chow 10 likewise saw no effect on the oxidation rates of HTGR graphites over a limited range of tensile stress, flow rate and temperature. Compressive stresses were applied to grades 2020 and H440 graphites by Thrower, who, again, found no effect of stress on oxidation rate. 11 Ima $i$ and Sasaki, however, found some increase in the rate of oxidation in air of $\mathrm{H} 327$ graphite prestressed in compression to $90 \%$ of the mean fracture stress; they also obtained data showing that the effect diminishes with increasing reaction temperature. 12 Since the results of these investigators are not entirely consistent, it was judged worthwhile to reinvestigate the effects of stress and prestress on oxidation and strength in more detail. Data concerning the effects of prestress on the oxidation rates and ultimate compressive and tensile strengths of graphite grades $H 451$ and PGX will be presented and discussed in this report. The former is a candidate for the core and reflector materials, while the latter is used for the core support blocks in the Fort St. Vrain HTGR. Additionally, data pertaining to the effect of stress during oxidation on the reaction rates of these graphites will be presented.

\section{EXPER IMENTAL}

\subsection{Materials}

The graphites used in this study were grades H451 (Great Lakes Carbon Corporation) and PGX (Union Carbide Corporation). Some properties of these graphites are summarized in Table 1. 
Table 1

Some Properties of the Materials Used in the Study

$\begin{array}{ccccc}\text { Density } & \text { Young's } \\ \left(\mathrm{g} / \mathrm{cm}^{3}\right) & \begin{array}{c}\text { Modulus } \\ \left(\mathrm{GN} / \mathrm{m}^{2}\right)\end{array} & \begin{array}{l}\text { Tensile } \\ \text { Strength } \\ \left(\mathrm{MN} / \mathrm{m}^{2}\right)\end{array} & \begin{array}{c}\text { Compressive } \\ \text { Strength } \\ \left(\mathrm{MN} / \mathrm{m}^{2}\right)\end{array} & \begin{array}{c}\text { Method of } \\ \text { Manufacture }\end{array}\end{array}$

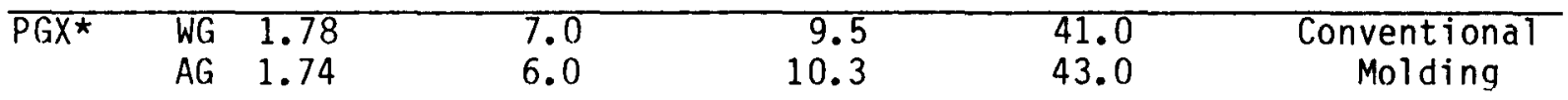

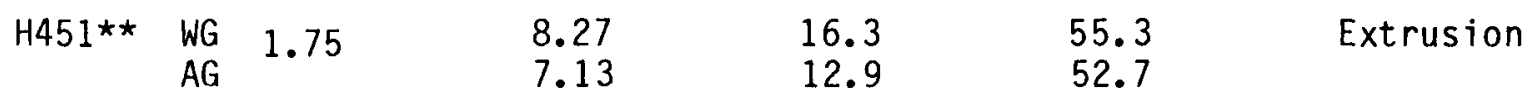

\footnotetext{
*After Johnson and Engle, GA-A-13752(1976)

**AFter Engle, GA-A-14328(1977)

Cylindrical compressive specimens $19.05 \mathrm{~mm} \phi$ by $38.10 \mathrm{~mm}$ in length were used for the experiments on the effect of prestress on the reaction rates and strengths of PGX and H451 graphites. Specimens of the former were machined from a half-moon shaped block of $P G X$ graphite $48 \mathrm{~cm}$ in radius and $9 \mathrm{~cm}$ thick which was cut from a mid-length portion of a production grade block ca. $127 \mathrm{~cm}$ $\phi$ by $196 \mathrm{~cm}$ length. H451 specimens were machined from a half-moon shaped $\mathrm{H} 451$ graphite block $(46 \mathrm{~cm} \phi$ by $15 \mathrm{~cm}$ thickness) which was cut from a mid-length portion of a production grade block $86 \mathrm{~cm}$ in length. The longitudinal axis of the H451 specimens was parallel to the grain, while the axis of the PGX specimens was perpendicular to it.
}

For the experiments on stress-during-oxidation, two kinds of cylindrical specimens were used. Compressive specimens of PGX and $H 451$ measured $12.7 \mathrm{~mm} \phi$ by $25.4 \mathrm{~mm}$ length. Tensile specimens measured $12.7 \mathrm{~mm}$ by $168.3 \mathrm{~mm}$ length; machine threads were put on both ends of the tensile specimens used in the stress experiments, according to the dimensions in the drawing in Fiqure 1. The longitudinal axis of all the $\mathrm{H} 45 \mathrm{l}$ and PGX graphite specimens was parallel to the radial direction of their parent blocks; these half-moon shaped blocks measured $43 \mathrm{~cm}$ कby $17 \mathrm{~cm}$ length (H451) and $54 \mathrm{~cm} \phi$ by $9 \mathrm{~cm}$ length (PGX).

Prior to use, all the specimens were cleaned ultrasonically in absolute methanol and dried in air at 75 to $80^{\circ} \mathrm{C}$ for about $10 \mathrm{hr}$.

\subsection{Experiments on Tensile and Compressive Stresses before Oxidation}

Prestressing and Strength Measurements:

In the prestress experiments, compressive prestresses were applied along the longitudinal axis of the specimens to a stress level between 25 and $90 \%$ of the mean compressive strength of each graphite. The strain rate was $1.1 \times 10^{-3} \mathrm{sec}^{-1}$. The residual strain caused by prestressing ranged from 0 to $0.4 \%$ (depending on prestress level and kind of graphite), a part of which was recovered during oxidation in air or water vapor/helium mixture. Prestressing and strength measurements of the larger compressive specimens were 

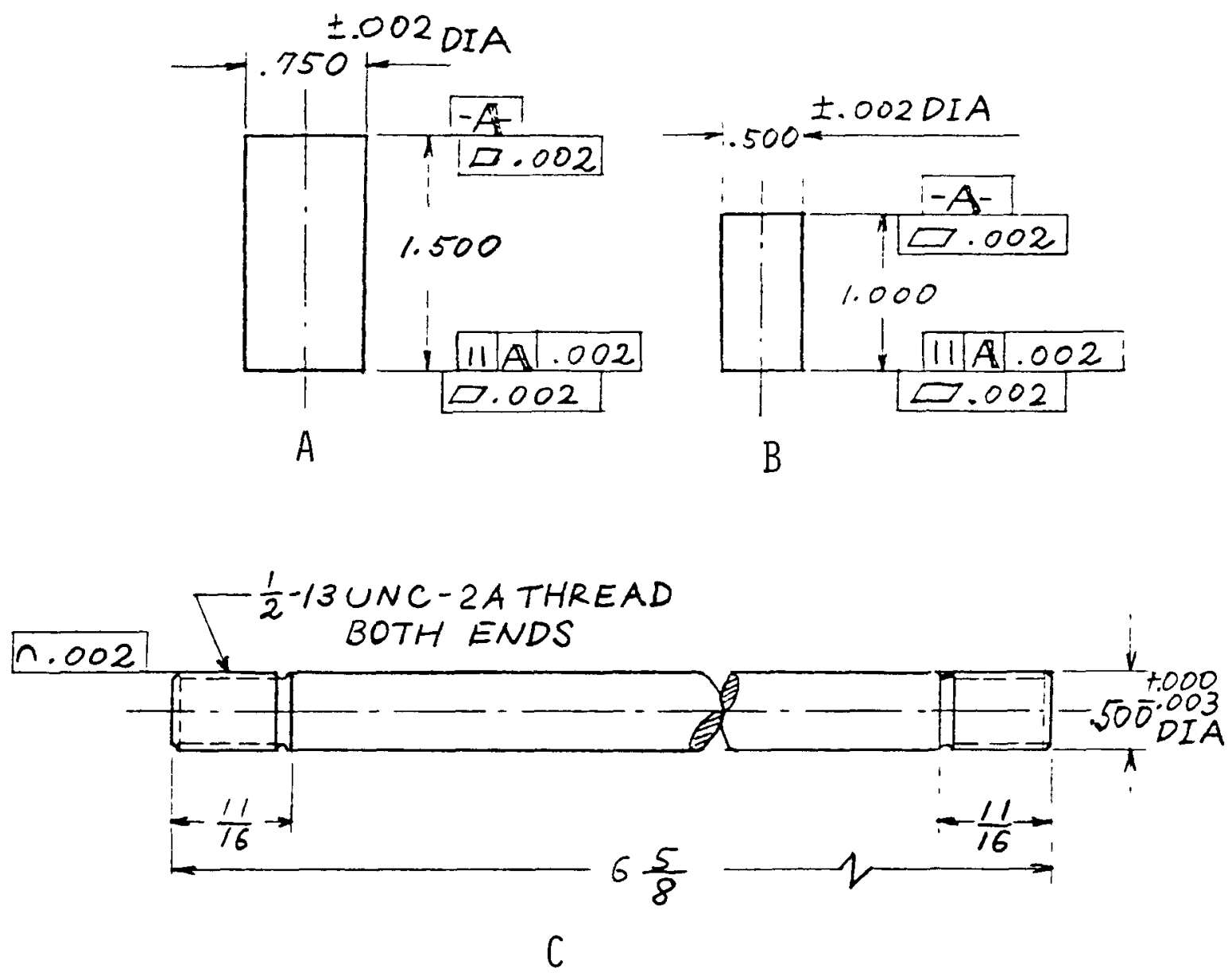

Figure 1. Dimensions (in inches) of the Specimens Used in the Present Experiments: (A) and (B), Compressive Specimen; (C) Tensile Specimen for Stress Rig. 
carried out using a Tinius 01 sen Universal Test Machine with maximum allowable load of ca. 5.45 tons. These strength tests were also done at a strain rate of $1.1 \times 10^{-3} \mathrm{sec}^{-1}$.

\section{Oxidation:}

Oxidation of specimens was carried out in a quartz tube through which various atmospheres such as air and $2 \% \mathrm{H}_{2} \mathrm{O} / \mathrm{He}$ with or without $\mathrm{H}_{2}$ were passed, generally at a flow rate of $300 \mathrm{sccm}$. Higher flow rates were necessary in a few cases (high oxidation rates) to limit conversion of the oxidant to $<5 \%$. Gas metering was performed with Aalborg flow controllers which had been calibrated against Tylan electronic flow controllers. The water vapor mixtures were made by passing helium with or without hydrogen either over a 9:1 mixture of oxalic acid dihydate $\left(\mathrm{H}_{2} \mathrm{C}_{2} \mathrm{O}_{4} \cdot 2 \mathrm{H}_{2} \mathrm{O}\right)$ : oxalic acid anhydrate $\left(\mathrm{H}_{2} \mathrm{C}_{2} \mathrm{O}_{4}\right)$ maintained at $50^{\circ} \mathrm{C}$ or through a bubbler containing doublydistilled $\mathrm{H}_{2} \mathrm{O}$ which was maintained at $\mathrm{ca} .18^{\circ} \mathrm{C}$. Both blended mixtures provided water vapor at a concentation of ca. $2 \%$.

Reaction temperatures ranged from 400 to $650^{\circ} \mathrm{C}$ for oxidation in air and 550 to $\mathrm{ca} .900^{\circ} \mathrm{C}$ for oxidation in $2 \% \mathrm{H}_{2} \mathrm{O} / \mathrm{He}$ with or without $\mathrm{H}_{2}$.

\subsection{Experiments on Tensile and Compressive Stresses during 0xidation}

A stress rig was set up to examine the effect of tensile and compressive stresses during oxidation on the reaction rates of $P G X$ and $H 451$ graphites in $2 \% \mathrm{H}_{2} \mathrm{O} / \mathrm{He}$. Figure 2 shows the main part of the rig. A quartz tube $100 \mathrm{~mm}$ $0 . D$. by $96 \mathrm{~mm} \mathrm{I.D.} \mathrm{enveloped} \mathrm{the} \mathrm{rig} \mathrm{and} \mathrm{served} \mathrm{as} \mathrm{a} \mathrm{containment} \mathrm{vessel} \mathrm{for}$ the gaseous reactants. Three tensile and three compressive specimens were stressed during oxidation by applying a load to the lower pul1-rod using an air piston. The stress level ranged from 0 to $55 \%$ of the mean tensile or compressive strength. The experiments were carried out at 650 or $700^{\circ} \mathrm{C}$ with a reactant flow rate of $300 \mathrm{sccm}$. A view of the stress rig is shown in Figure 3.

\subsection{Measurements of Reaction Rate}

Reaction rates for oxidation in different atmospheres were calculated from the concentrations of the carbon-containing product gases, which were monitored with a Carle Analytical Gas Chromatograph Model 311. Methanation of these gases followed by analysis with an FID gave rise to minimum detectable limits of 20 and $50 \mathrm{ppb}$ for $\mathrm{CO}_{2}$ and $\mathrm{CO}$, respectively. All other species were measured with a thermistor TCD. The detectors were calibrated with mixtures of gases of similar composition as that of the product gases. The oxidation rate is given by the weight loss expression

$$
-\frac{d W_{c}}{d t}=\frac{12 q}{R T} \sum_{i} \frac{P_{j}}{v_{i}},
$$




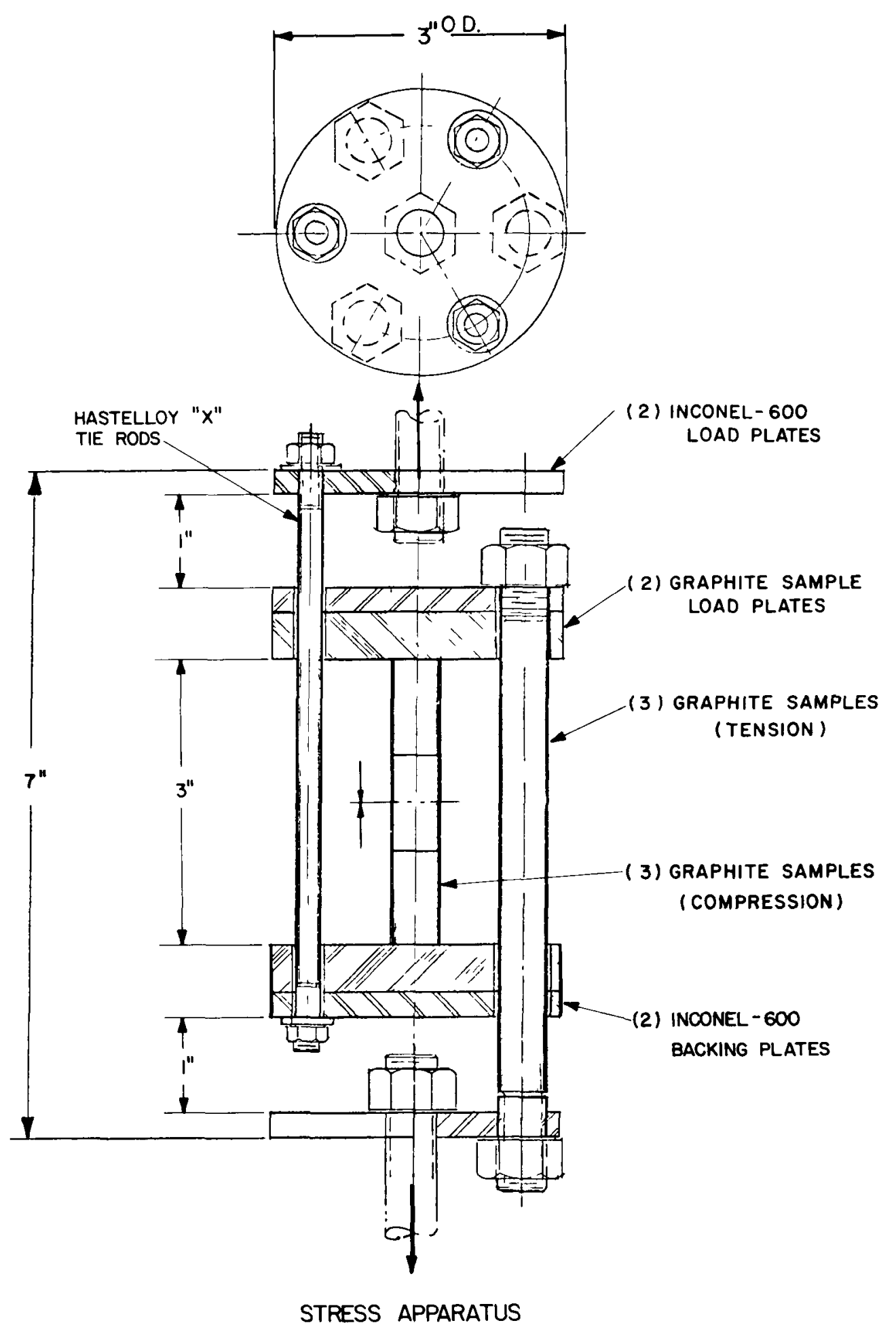

Figure 2. Schematic of the llain Part of the Stress Rig 


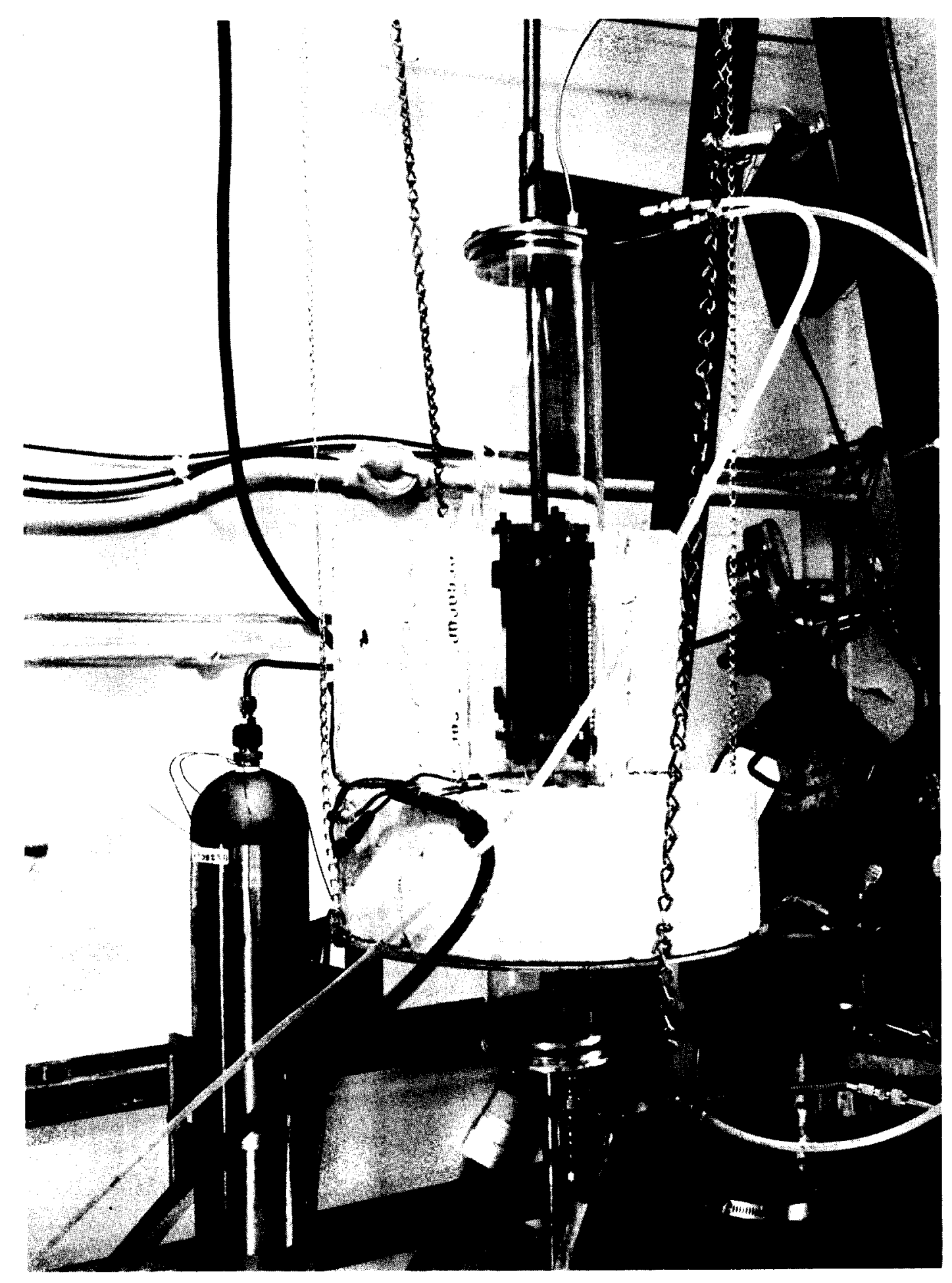

Figure 3. Overview of the Stress Experiment 
where $W_{c}$ is the weight of carbon, $q$ is the flow rate of the gas mixture, $P_{j}$ is the partial pressure of carbon-containing product species, and $v_{j}$ is a stoichiometric coefficient (e.g., ${ }^{\nu} \mathrm{CO}=2$ for $\left.\mathrm{C}+\mathrm{CO}_{2} \rightarrow 2 \mathrm{CO}\right)$.

The mean reaction rate for each oxidation experiment was estimated from the weight loss of a specimen and the reaction time.

\section{RESULTS AND DISCUSSION}

\subsection{Effect of Prestress on Strength and 0xidation Rate}

The compressive strength of $\mathrm{PGX}$ graphite oxidized in a $2 \% \mathrm{H}_{2} \mathrm{O} / \mathrm{He}$ mixture (with or without $\mathrm{H}_{2}$ ) and in air is plotted in Figure 4 as a function of burnoff. In the case of $2 \% \mathrm{H}_{2} \mathrm{O} / \mathrm{H}_{2} / \mathrm{He}$, the flow rate of $\mathrm{H}_{2}$ was set at $120 \mathrm{sccm}$ and that of $\mathrm{He}$ at $480 \mathrm{sccm}$, giving $\left[\mathrm{H}_{2}\right]=20 \%$.

The data obtained for H451 graphite are shown in Figure 5 , where the specimens were oxidized either in a $2 \% \mathrm{H}_{2} 0 / \mathrm{He}$ mixture or in air, with or without prestress up to $75 \%$ of the mean strength.

Effect of prestress on strength:

The results displayed in Figures 4 and 5 indicate that prestressing these graphites up to $90 \%$ of the mean strength does not affect their compressive strengths. In the temperature ranges examined, the strength loss does not depend on the reaction temperature either, which is believed to indicate that burnoff of all these specimens occurred in a similar manner. This is discussed el sewhere.13

It has been claimed that compressive prestress has no effect on the $u$ Itimate compressive strength of unoxidized graphites ${ }^{5}$, though many physical properties such as coefficient of thermal expansion, electrical resistivity and Young's modulus are drastically influenced by prestress. $2-4,6,7$ It is also believed that the compressive strength of both unoxidized and oxidized graphites is not very sensitive to microstructural changes.

\section{Effect of prestress on reaction rate:}

Figure 6 illustrates the time dependence of the reaction rate of $P G X$ graphite specimens prestressed to various levels and oxidized at $500^{\circ} \mathrm{C}$ in air. The rates of prestressed specimens lie within the scatter band. The oxidation rate in a $2 \% \mathrm{H}_{2} \mathrm{O} / \mathrm{He}$ mixture at $100^{\circ} \mathrm{C}$ is plotted as a function of exposure time in Figure 7. The open circles represent the oxidation rate before stressing and filled circles represent the rate after stressing.

The figure indicates that no enhancement of the rate of PGX graphite results from the application of prestress at room temperature. This result does not agree with that obtained for H327 graphite by other investigators. 12 


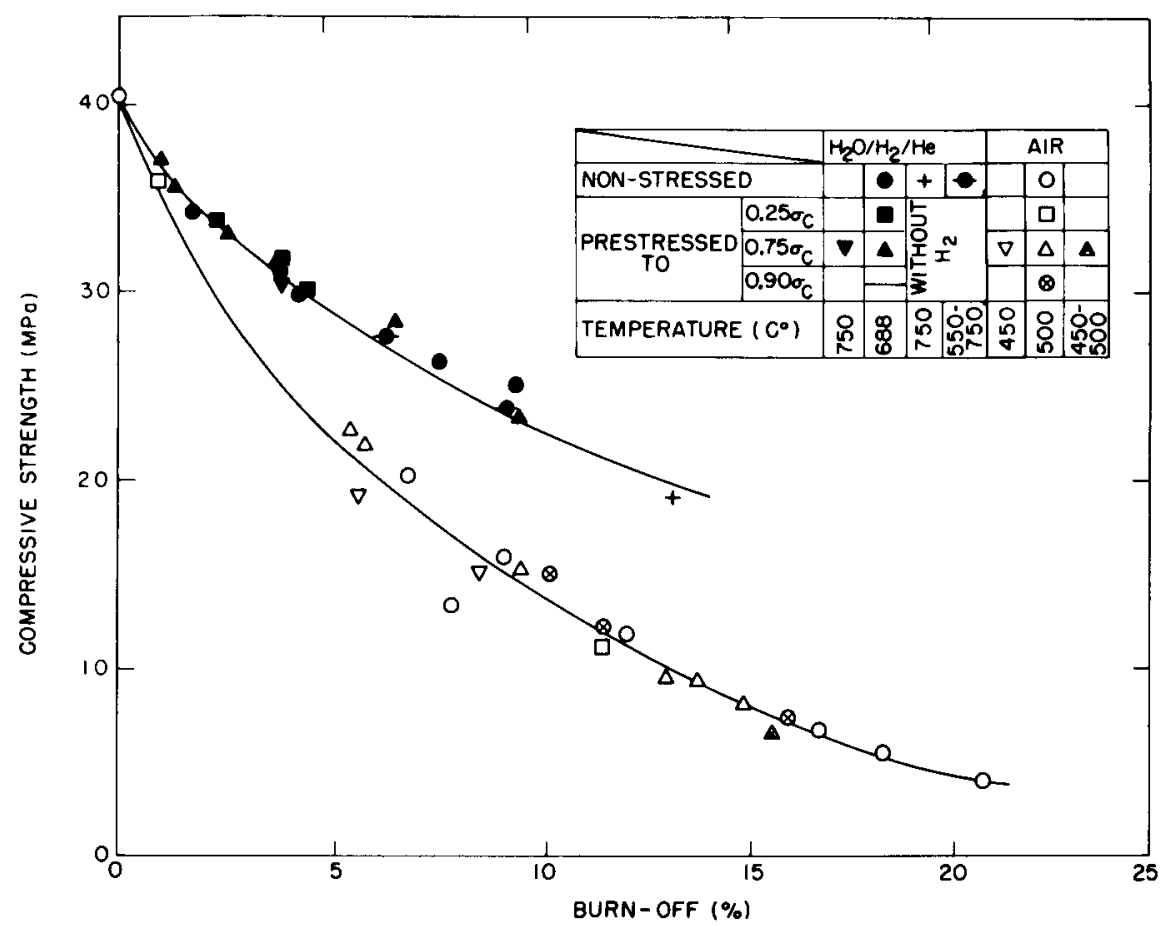

Figure 4. Compressive Strength of Prestressed or Non-Stressed PGX Graphite 0xidized in Air or in $2 \% \mathrm{H}_{2} \mathrm{O} /\left(20 \% \mathrm{H}_{2}\right) / \mathrm{He}$ at Different Temperatures

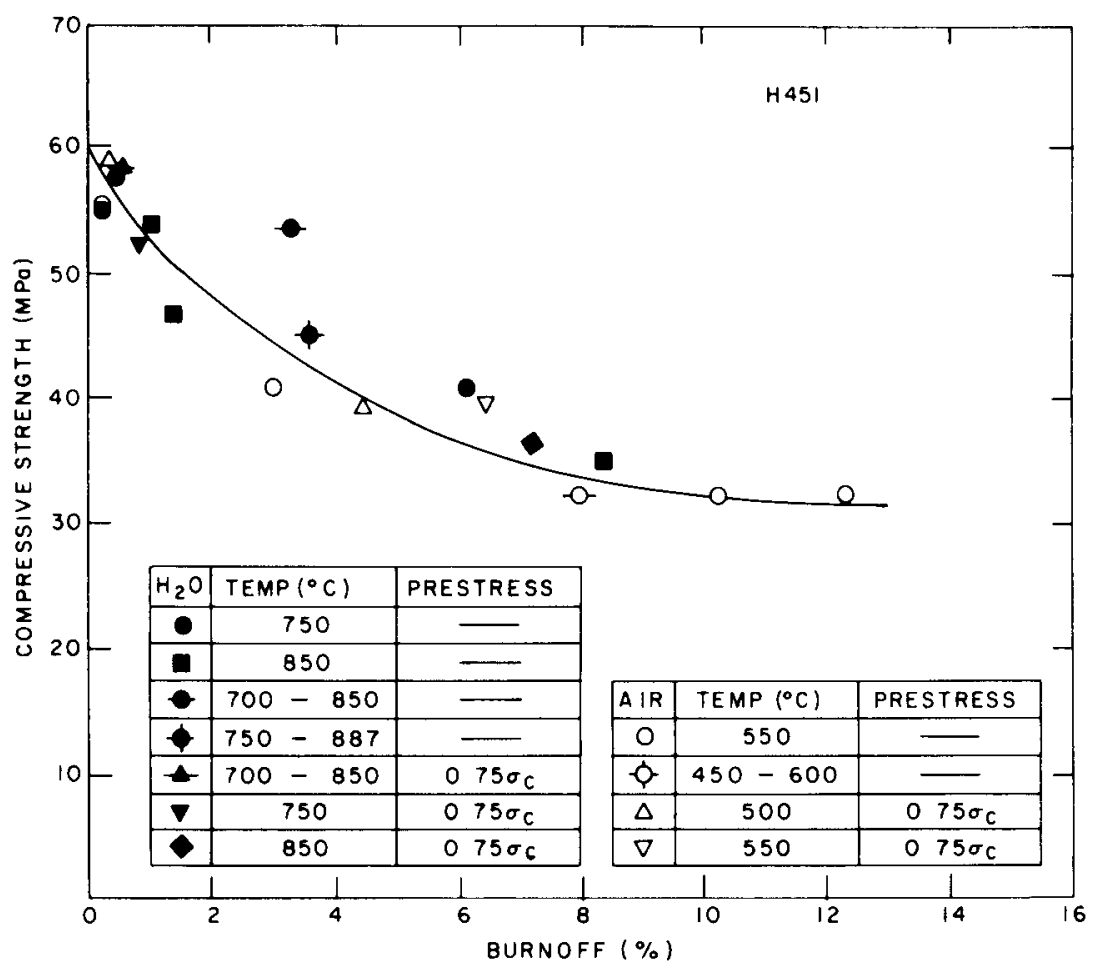

Figure 5. Compressive Strength of Prestressed or Non-Stressed H451 Graphite Oxidized in $\mathrm{Air}$ or in $2 \% \mathrm{H}_{2} \mathrm{O} / \mathrm{He}$ at Various Temperatures 


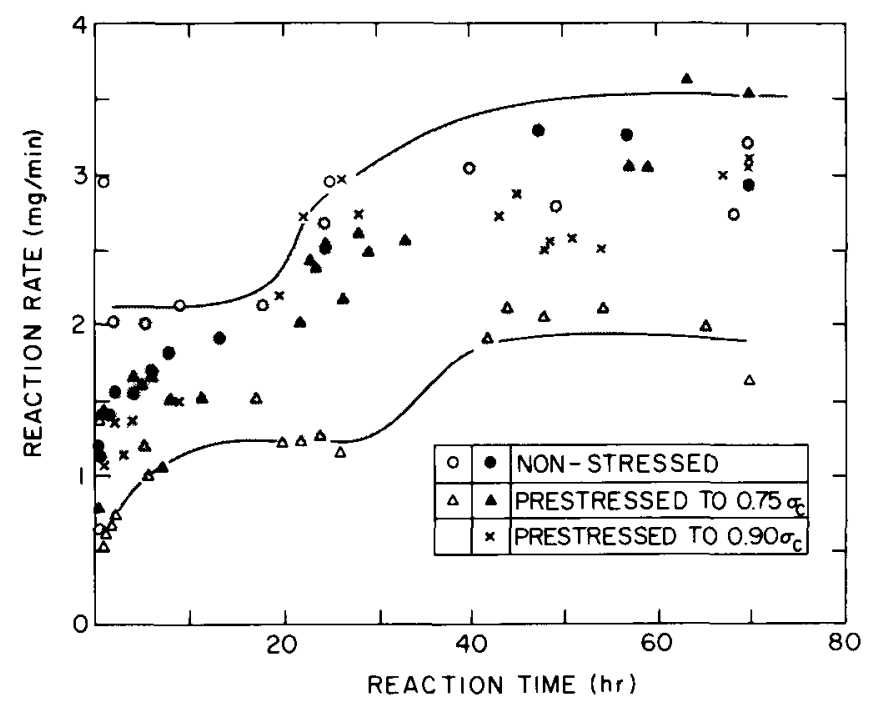

Figure 6. Reaction Rate of PGX Graphite Specimens Prestressed to Various Levels and 0xidized in Air at $500^{\circ} \mathrm{C}$ as a Function of Exposure Time

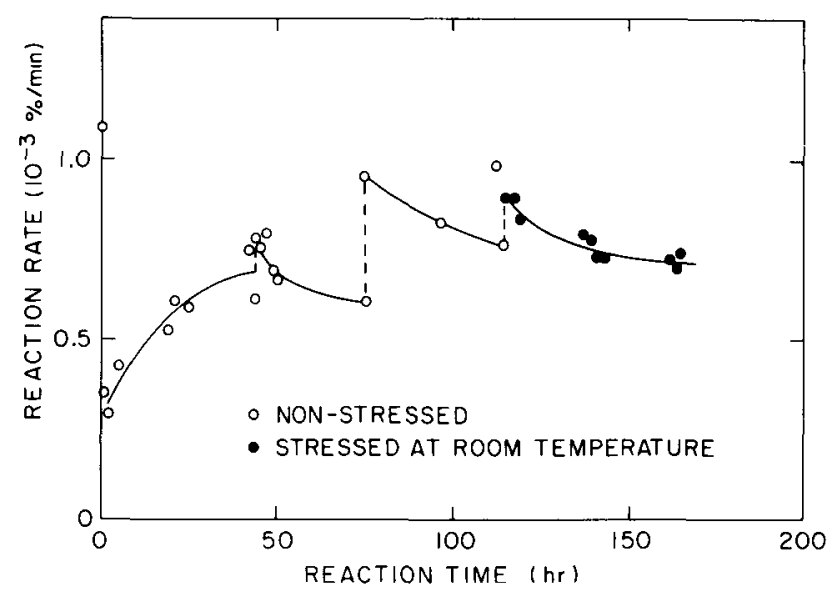

Figure 7. Reaction Rate of $P G X$ Graphite 0xidized in $2 \% \mathrm{H}_{2} \mathrm{O} / \mathrm{He}$ at $700^{\circ} \mathrm{C}$ as a Function of Exposure Time 
Similar experiments were done for $\mathrm{H} 451$ graphite oxidized in air and in $2 \%$ $\mathrm{H}_{2} \mathrm{O} / \mathrm{He}$. An $\mathrm{H} 451$ graphite specimen was first oxidized at $500^{\circ} \mathrm{C}$ or $550^{\circ} \mathrm{C}$ in air at $300 \mathrm{sccm}$ or at $750^{\circ} \mathrm{C}$ in $2 \% \mathrm{H}_{2} 0 / \mathrm{He}$ at $200 \mathrm{sccm}$ until a stabilized rate was obtained. The specimen was then stressed to $75 \%$ of its mean compressive strength, which was estimated from the results given in Figure 5. The results for air oxidation are shown in Figures 8 and 9; the observed rate increase of less than $15 \%$ is too small to be considered significant at this time. Figure 10 shows the result obtained for $\mathrm{H} 45 \mathrm{l}$ graphite oxidized in a $2 \% \mathrm{H}_{2} \mathrm{O} / \mathrm{He}$ mixture at $750^{\circ} \mathrm{C}$. The data indicate that prestress caused ca. $50 \%$ increase in the reaction rate. The data plotted in Figure 11 were obtained after oxidation had been permitted to continue for $40 \mathrm{hr}$. To confirm that the enhancement observed above was not an artifact, an $\mathrm{H} 451$ control specimen, which was prestressed to $75 \%$ of the mean compressive strength before the first run, was oxidized in a similar manner. This time no rate enhancement was observed upon reexposing the specimen to the oxidizing conditions. This can be seen in Figure 12. In these experiments maximum burnoff of the specimens was less than $1 \%$.

The oxidation rate was also measured for an $H 451$ graphite specimen which was prestresed in stepwise fashion, ranging from $25 \%$ to $85 \%$ of the mean compressive strength. The specimen was first oxidized in a $2 \% \mathrm{H}_{2} \mathrm{O} / \mathrm{He}$ mixture at $750^{\circ} \mathrm{C}$ at a flow rate of $300 \mathrm{sccm}$ until a stabilized rate of reaction was attained. Then the specimen was taken out of the reactor, given a prestress of $25 \%$ of the mean strength and oxidized in the same manner as before, until a stabilized rate was attained again. The same procedures were followed for prestressing to $50 \%$ and $85 \%$ of the mean compressive strength. The result is shown in Figure 13, where the maximum burnoff was ca. $0.4 \%$. This result suggests that a prestress level larger than $50 \%$ of mean compressive stength causes some enchancement of the reaction rate of $\mathrm{H} 451$ graphite. Figure 14 shows the stabilized rates in units of $\mathrm{g} / \mathrm{g} / \mathrm{min}$ versus prestress levels normalized to the mean compressive strength. It has been shown previously that substantial changes in various properties and microstructure are observed for different nuclear graphites if the applied stress level is higher than $50 \%$ of the ultimate compressive strength.2-4 The results obtained here suggest that reactivity may be enhanced by compressive prestresses greater than $50 \%$ of the mean strength, but the effect, if real, is not very large. This conclusion is consistent also with the results of Imai et al. 12 who obtained, for $\mathrm{H} 327$ graphite prestressed to $90 \%$ of the mean compressive strength and oxidized in air at $430^{\circ} \mathrm{C}$, a reaction rate twice as high as that obtained for unstressed specimens.

Imaj et al.12 also found that the enhancement of reaction rate was annealed out at higher temperatures; this suggests that the smaller effect observed in the present work, in the case of oxidation in air, may result from the higher oxidizing temperatures employed. In the case of H451 oxidized in $2 \% \mathrm{H}_{2} \mathrm{O} / \mathrm{He}$ at $750^{\circ} \mathrm{C}$ (Figures 10 and 13 ), the temperature is believed to be too high for the same mechanism to apply, which leads us to think that some unannealable defects, such as cracks initiated above ca. $50 \%$ of the mean strength, 3 are related to the enhancement of the rate.

The lack of effect observed in the case of PGX graphite oxidized in $2 \%$ $\mathrm{H}_{2} \mathrm{O} / \mathrm{He}$ may be attributed to the high concentration of impurities in this 


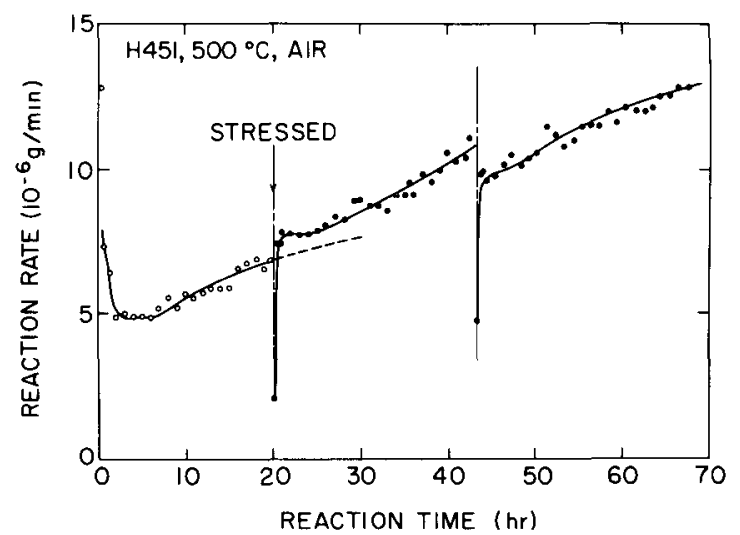

Figure 8. Rate of 0xidation of $\mathrm{H} 451$ Graphite in Air at $500^{\circ} \mathrm{C}$ as a Function of Exposure Time

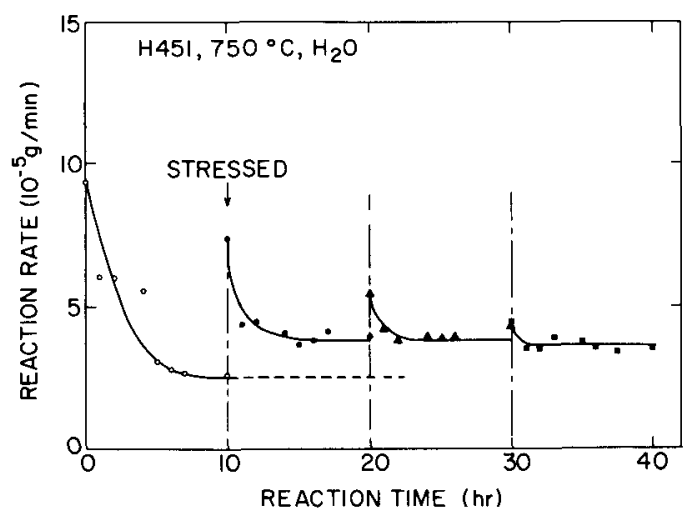

Figure 10. Rate of Oxidation of $\mathrm{H} 451$ Graphite in $2 \% \mathrm{H}_{2} \mathrm{O} / \mathrm{He}$ at $750^{\circ} \mathrm{C}$ as a Function of Exposure Time

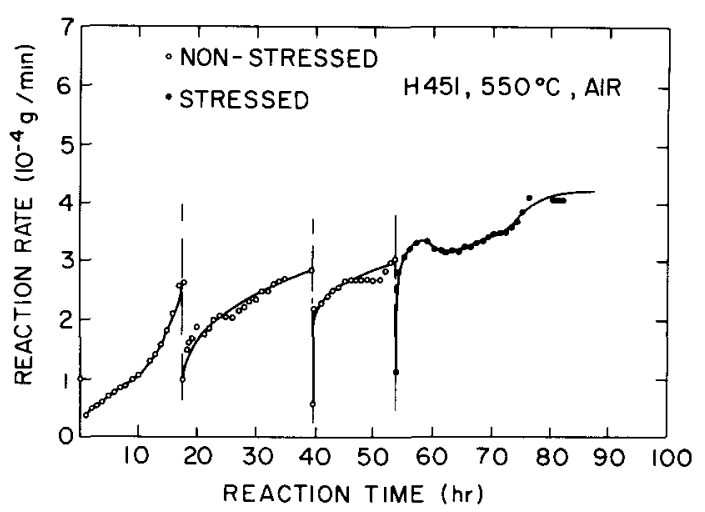

Figure 9. Rate of Oxidation of $\mathrm{H} 451$ Graphite in Air at $550^{\circ} \mathrm{C}$ as a Function of Exposure Time

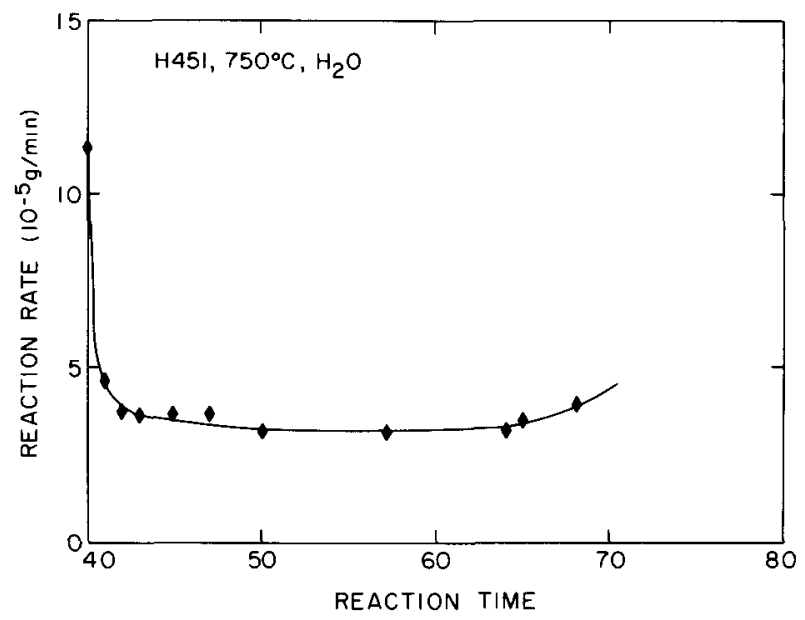

Figure 11. Reaction Rate as a Function of Exposure Time for the H451 Graphite Specimen Shown in Figure 10 After 40 $\mathrm{Hr}$. of Exposure 


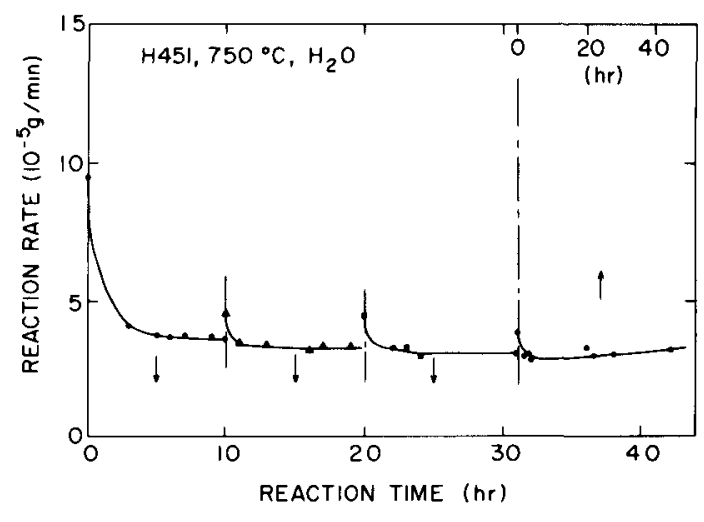

Figure 12. Reaction Rate of an H451 Control' Specimen, Which Was Prestressed to $75 \%$ of the Mean Compressive Strength Before the First Run, as a Function of Exposure Time

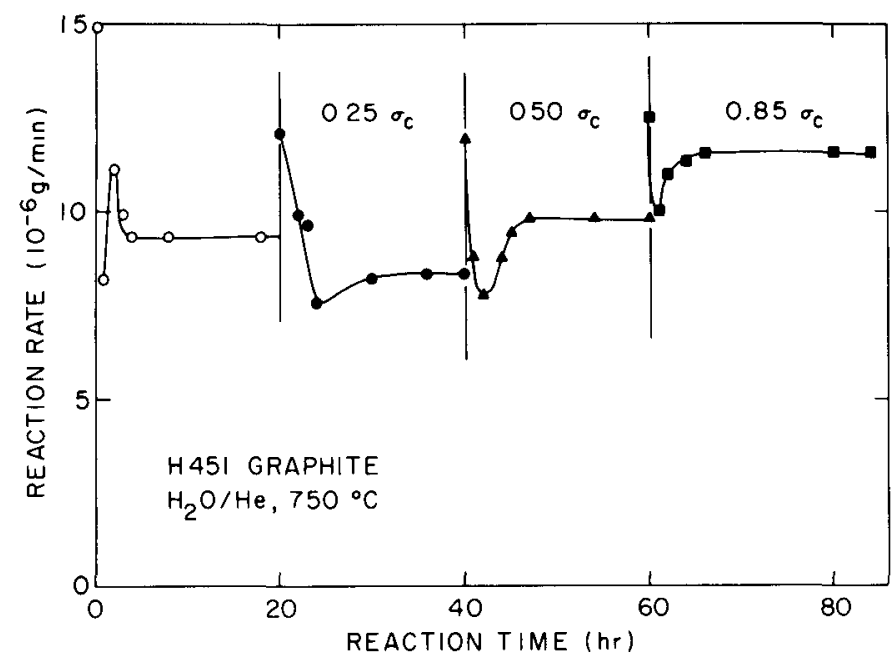

Figure 13. Reaction Rate of an H451 Graphite Specimen Which Was Prestressed in Stepwise Fashion and 0xidized in $2 \% \mathrm{H}_{2} \mathrm{O} / \mathrm{He}$ at $750^{\circ} \mathrm{C}$

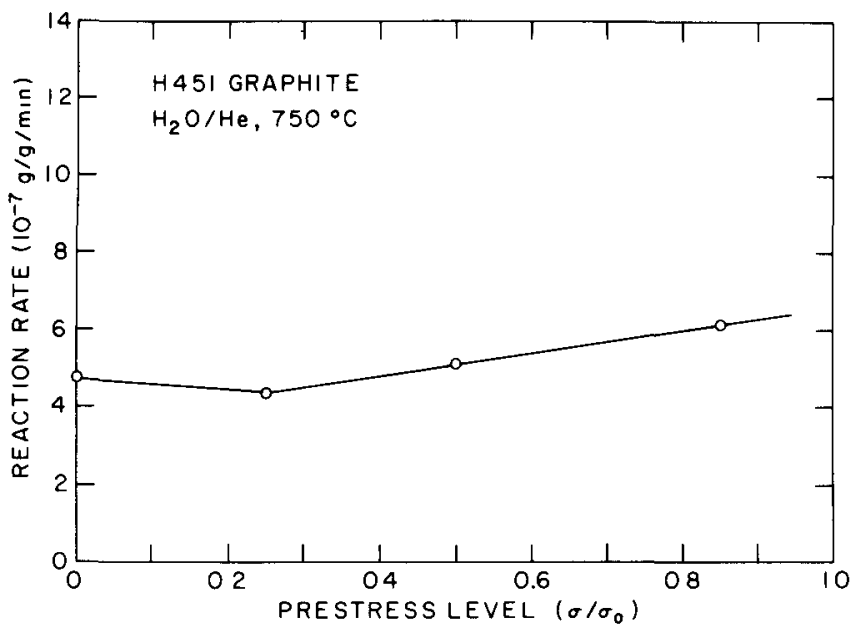

Figure 14. Stabilized Reaction Rate of H451 Graphite Specimen Which Was Prestressed in Stepwise Fashion as a Function of Normalized Prestress Level 
material; impurities such as iron may act as catalysts for the oxidation and mask the effect of structural changes produced by prestress. This point will be discussed elsewhere in a report dealing with the strength loss mechanisms in nuclear graphites. 13

\subsection{Effect of Stress during 0xidation on Reaction Rate}

The effect of stress applied during oxidation on the reaction rates of $P G X$ and $\mathrm{H} 451$ graphites was studied using compressive loads of up to $44 \%$ and $28 \%$, respectively, of the graphites' ultimate compressive strength and tensile loads of $56 \%$ and $35 \%$, respectively, of the graphites' ultimate tensile strength.

The results for PGX graphite oxidized at $440^{\circ}$ and $650^{\circ} \mathrm{C}$ in $2 \% \mathrm{H}_{2} \mathrm{O} / \mathrm{He}$ are plotted in Figures 15 to 17 in the form reaction rate vs. time. Application of stress during the oxidation, even in alternating fashion -- stress, no stress, stress -- did not produce any measurable difference in the reaction rates. Results for $\mathrm{H} 451$ graphite, likewise oxidized in $2 \% \mathrm{H}_{2} \mathrm{O} / \mathrm{He}$ but at a temperature of $700^{\circ} \mathrm{C}$, are shown in Figure 18. Here again no effect of stress on reaction rate was observed.

These results are consistent with all known data on the effect of stress on reactivity, except that of Krefeld et al. 8 It is possible that the experimental parameters were not in the proper range to see such an effect: the stress loads may have been too small, stress may have been applied for too short a time, the temperature may have been too low, or a combination of these may have been at work. However, data have been gathered by other workers over a wide range of conditions, even using flow rates, temperatures, and materials similar to those of the Petten workers; no effect whatsoever of stress on reactivity has been observed in any of these cases. One cannot exclude the possibility, however, that at very high stress levels some enhancement of the reaction may occur, such as appears to be the case in prestress experiments.

\section{CONCLUSIONS}

The effects of prestress on the reactivities and ultimate compressive strengths of $P G X$ and $H 451$ graphites have been examined. Little or no effect of prestressing these graphites, generally up to $75 \%$ of the mean fracture strength, was found when these graphites were oxidized in air or $2 \% \mathrm{H}_{2} \mathrm{O} / \mathrm{He}$. There may be a small effect on the reactivity of $\mathrm{H} 451$ graphite oxidized in $2 \%$ $\mathrm{H}_{2} \mathrm{O} / \mathrm{He}$, but even in this case the rate is enhanced by no more than $30 \%$ for prestress levels less than $90 \%$ of the ultimate compressive strength.

The effect of stress during oxidation on the reactivities of nuclear graphites in $2 \% \mathrm{H}_{2} \mathrm{O} / \mathrm{He}$ was also investigated. The results, which are consistent with those of most investigators, indicate that stress does not affect the reactivities of $\mathrm{H} 451$ and PGX graphites. Maximum stress levels used for $\mathrm{H} 451$ graphite were $28 \%$ of the mean compressive strength and $35 \%$ of the mean tensile strength. Maximum stress levels used for PGX graphite were $44 \%$ of the mean compressive strength and $56 \%$ of the mean tensile strength. 


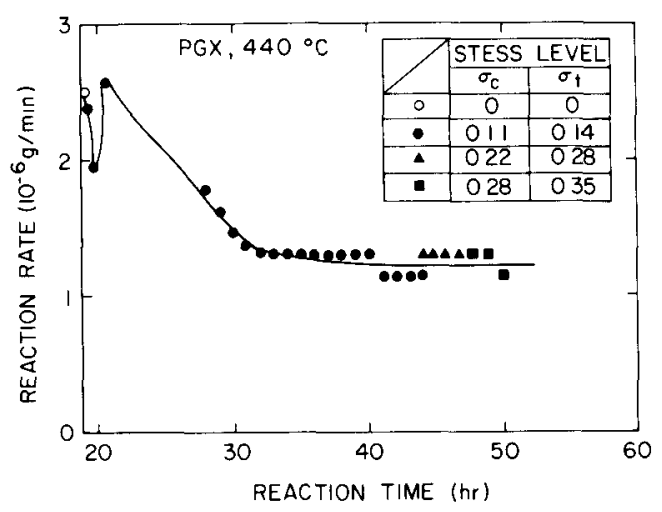

Figure 15. Reaction Rate vs. Exposure Time of PGX Graphite Subjected to Various Levels of Stress While Being oxidized at $400^{\circ} \mathrm{C}$ in $2 \% \mathrm{H}_{2} \mathrm{O} / \mathrm{He}$

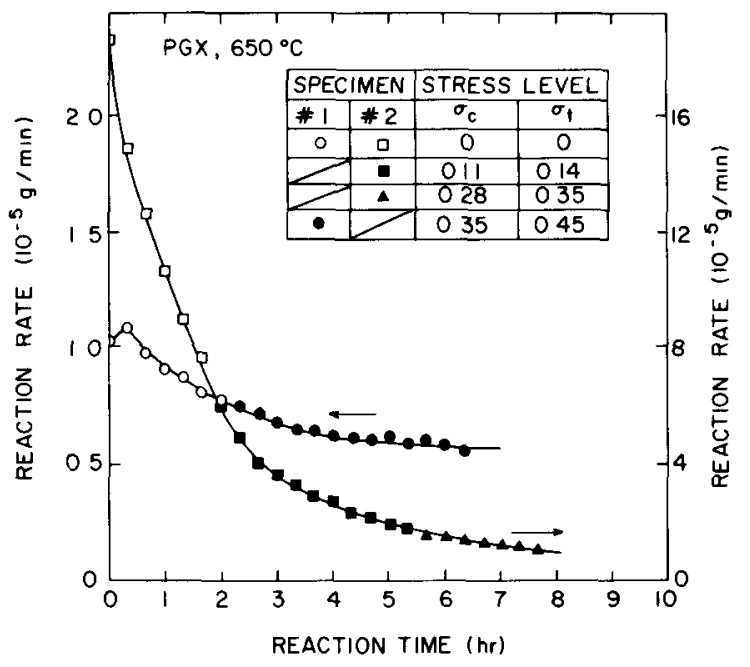

Figure 17. Reaction Rate vs. Exposure Time of PGX Graphite Subjected to Various Stress Levels While Being oxidized at $650^{\circ} \mathrm{C}$ in $2 \% \mathrm{H}_{2} \mathrm{O} / \mathrm{He}$

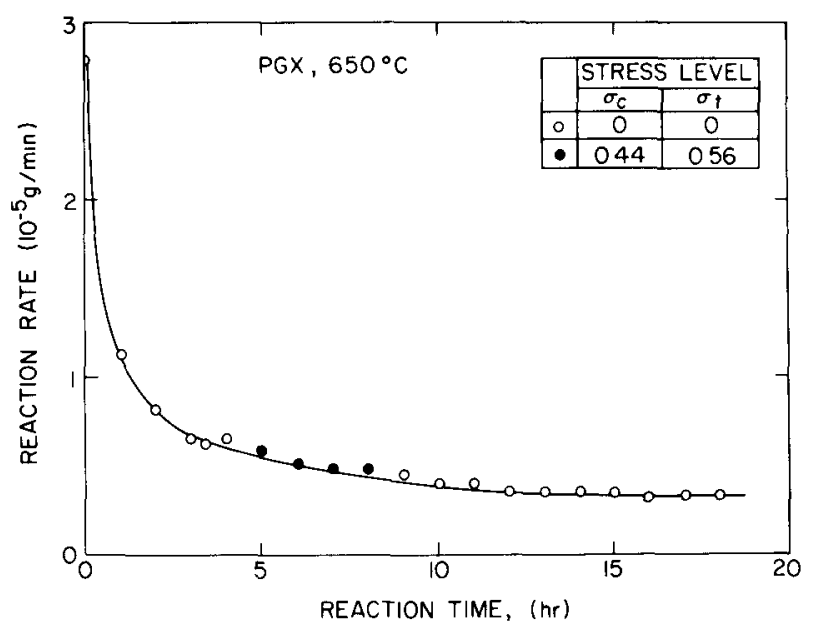

Figure 16. Reaction Rate vs. Exposure Time of PGX Graphite Oxidized Under Stress at $650^{\circ} \mathrm{C}$ in $2 \% \mathrm{H}_{2} \mathrm{O} / \mathrm{He}$

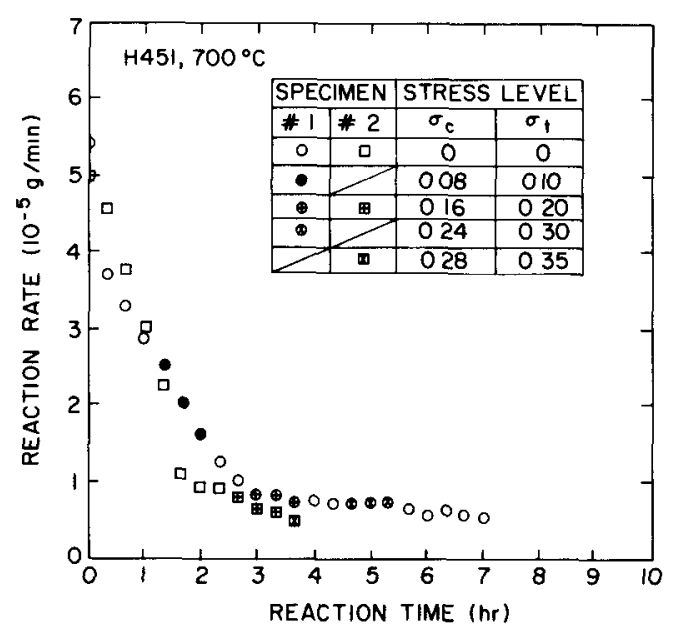

Figure 18. Reaction Rate vs. Exposure Time of H451 Graphite Subjected to Various Levels of Stress While Being oxidized at $700^{\circ} \mathrm{C}$ in $2 \% \mathrm{H}_{2} \mathrm{O} / \mathrm{He}$ 


\section{ACKNOWLEDGEMENTS}

The authors would like to thank J. G. Y. Chow for helpful discussions and C. C. Finfrock, J. H. Heiser, III and J. J. Barry for help with machining, oxidizing, and strength testing of some of the specimens. Special thanks to C. Sastre and D. Schweitzer for their guidance and encouragement.

\section{REFERENCES}

1. Peroomian, M. B., Barsel1, A. W., and Saeger, J. C., GA-A12493, January 1974.

2. Hart, P. E., Carbon 10, 233 (1972).

3. Eto, M., Usui, T., and Oku, T., J. Nucl. Mater. 45, 347 (1972/73).

4. Eto, M. and 0ku, T., J. Nucl. Mater. 46, 315 (1973).

5. Oku, T. and Eto, M., Carbon 11, 639 (1973).

6. Eto, M. and Oku, T., J. Nucl. Mater. 54, 245 (1974).

7. Oku, T., Usui, T., Eto, M., and Fukuda, Y., Carbon 15, 3 (1977).

8. Krefeld, R., Linkenheil, C. and Karcher, W., 11th Biennial Carbon Conference, Gatilinburg, Tennessee, ORNL-Conf-730601 (1973) p. 88.

9. Private communication.

10. Growcock, F. B. and Chow, J. G. Y., BNL-NUREG-24672 (1978).

11. Thrower, P. A., Progress Rept. Feb. 1, 1976 - Jan. 31, 1977, C00-2712-2 (1977).

12. Imai, H., Nomura, S., Kurosawa, T., Fujii, K., and Sasaki, Y., Tanso (in Japanese), in press.

13. Eto, M. and Growcock, F. B., "Effect of Oxidizing Environment on the Strength and 0xidation Kinetics of HTGR Graphites. Part I: Reactivity and Strength Loss of H451, PGX and IG-11 Graphites," Brookhaven National Laboratory, in press. 
Brookhaven National Laboratory

M. Eto (15)

F. B. Growcock (10)

W. Y. Kato

D. G. Schweitzer (2)

C. Sastre (2)

HTGR Safety Division (10)
A. Beavan, GA
W. Delle, KFA (Julich)
W. Eatherly (2), ORNL
G. Engle, GA
R. Foulds (2), NRC
W. Katscher, KFA (Jul ich)
Mr. Kubaschewski, KFA (Julich)
W. C. Morgan, PNL (Richland)
P. Thrower, Penna. State Univ.
P. Walker, Penna. State Univ. 